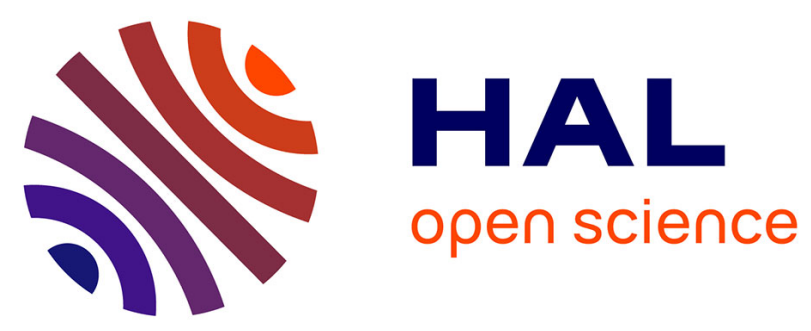

\title{
Impact of Nanostructuration on the Chemical Composition of Nickel Oxide Nanoparticles
}

Baptiste Polteau, François Cheviré, Franck Tessier, Philippe Deniard, Eric

Gautron, Laurent Cario, Stéphane Jobic

\section{- To cite this version:}

Baptiste Polteau, François Cheviré, Franck Tessier, Philippe Deniard, Eric Gautron, et al.. Impact of Nanostructuration on the Chemical Composition of Nickel Oxide Nanoparticles. Inorganic Chemistry, 2019, 58 (22), pp.15004-15007. 10.1021/acs.inorgchem.9b02088 . hal-02333977

HAL Id: hal-02333977

https://hal-univ-rennes1.archives-ouvertes.fr/hal-02333977

Submitted on 11 Dec 2019

HAL is a multi-disciplinary open access archive for the deposit and dissemination of scientific research documents, whether they are published or not. The documents may come from teaching and research institutions in France or abroad, or from public or private research centers.
L'archive ouverte pluridisciplinaire HAL, est destinée au dépôt et à la diffusion de documents scientifiques de niveau recherche, publiés ou non, émanant des établissements d'enseignement et de recherche français ou étrangers, des laboratoires publics ou privés. 


\title{
Impact of the nanostructuration on the chemical composition of nickel oxide nanoparticles
}

\author{
Baptiste Polteau, ${ }^{\dagger,}$ François Cheviré, ${ }^{*}{ }^{\dagger}$ Franck Tessier, ${ }^{\dagger}$ Philippe Deniard, ${ }^{\ddagger}$ Eric Gautron, ${ }^{\ddagger}$ Laurent \\ Cario, ${ }^{\ddagger}$ and Stéphane Jobic*, ${ }^{*}$ \\ ${ }^{\dagger}$ Univ Rennes, CNRS, ISCR - UMR 6226, F-35000 Rennes, France \\ ${ }^{\ddagger}$ Institut des Matériaux Jean Rouxel, Université de Nantes, CNRS, 2 rue de la Houssinière, 44322 Nantes cedex 03, France \\ Supporting Information Placeholder
}

\begin{abstract}
Reduction of the size of a particle down to a few tens of nanometer or below may drastically affect its physical properties. That is well known for quantum dots. Conversely, many works consider the chemical composition of nanoparticles as invariant when reducing their dimension. Here we demonstrate that the chemical composition of a transition metal oxide, namely nickel oxide, is drastically affected by its nanostructuration.
\end{abstract}

Nickel oxide is a well-known, strategic material that gives rise to many applications. Hence it is used in domains as diverse as solid oxide fuel cells, ${ }^{1-3}$ lithium batteries, ${ }^{4-6}$ electrochromic devices, ${ }^{7-9}$ gas sensors, ${ }^{10-12}$ (photo)catalysis, ${ }^{13-15}$ and solar cells. ${ }^{16-18}$ More recently, this material has been envisioned for potential memory devices due to its reversible resistance switching capability. ${ }^{19-21}$ Finally $\mathrm{NiO}$ nanoparticles are also investigated for their interesting magnetic properties that are still under debate. ${ }^{22-24}$

$\mathrm{NiO}$ crystallizes in the rock salt structure. In its 1:1 stoichiometric bulky form, the material is antiferromagnetic below $523 \mathrm{~K}$, and exhibits a pale green color with a low electrical conductivity. ${ }^{25-27}$ Simultaneously, $\mathrm{NiO}$ in the form of nanoparticles is regularly reported with different physical characteristics. Namely, a ptype semi-conductivity, a black color, or ferromagnetism are often observed. ${ }^{22-24,28-32}$ In that context, we have embarked on the synthesis of $\mathrm{NiO}$ nanoparticles and their (micro)structure characterization to shed light on the impact of the nanostructuration on the $\mathrm{Ni}: \mathrm{O}$ atomic ratio.

$\mathrm{NiO}$ materials were synthesized by thermal decomposition of $\mathrm{Ni}_{3} \mathrm{O}_{2}(\mathrm{OH})_{4}$ as prepared by Polteau et $a l .{ }^{33}$ Hereafter samples labelled $\mathrm{NiO}-\mathrm{T}$ will refer as to materials prepared at the synthesis temperature $\mathrm{T}\left({ }^{\circ} \mathrm{C}\right)$. For $\mathrm{T}$ in the $250-500^{\circ} \mathrm{C}$ and $500-800^{\circ} \mathrm{C}$ ranges, materials exhibited a black and grey color, respectively. Above $800^{\circ} \mathrm{C}, \mathrm{NiO}$ was greenish (see details in SI and Figures $\mathbf{S 1 - S 2}$ ).

Rietveld refinements were carried out on patterns collected at room temperature (RT) on each NiO-T sample. Hereafter, the "NiO" notation will stand for samples with diffraction peaks that can be fully indexed on the basis of the crystal structure of $\mathrm{NiO}$ even if the chemical formulae may significantly differ from the exact 1:1 atomic ratio. Refinements clearly evidenced a strong enlargement of coherent diffracting domains (i.e. CS) from 2 to 3 , $4,7,14,22,32,66$ and $193 \mathrm{~nm}$ for synthesis temperatures of 250 , $300,350,400,450,500,600,700$ and $800^{\circ} \mathrm{C}$, respectively (Figure 1 and Table S1). This evolution was fully asserted by transmission electron microscopy investigations (Figures S3-S4) that revealed well crystallized materials with a low distribution of particle size. The average particle sizes found from the examination of micrographs is almost identical to CS determined by XRD (Table S1). Consequently, nanoparticles can be viewed as single crystals, and not as an assembly of crystallites, i.e. grains.

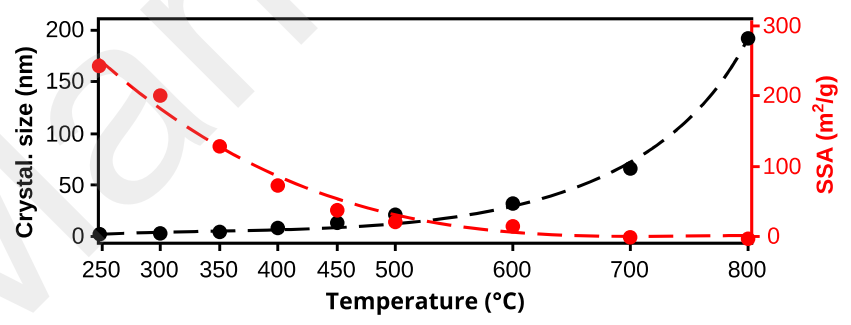

Figure 1. Crystallite size (CS) (black dots) and specific surface area (red dots) of "NiO" samples prepared from $\mathrm{Ni}_{3} \mathrm{O}_{2}(\mathrm{OH})_{4}$ at temperatures ranging from $250^{\circ} \mathrm{C}$ to $800^{\circ} \mathrm{C}$.

This reduction of the nanoparticule size with increasing temperature goes along with a strong diminution of the specific surface areas (SSA) of NiO-T samples that were determined by the Brunauer-Emmett-Teller method. Figure 1 displays the evolution of SSA vs. T and evidences a continuous decrease from $240 \mathrm{~m}^{2} / \mathrm{g}$ to $3 \mathrm{~m}^{2} / \mathrm{g}$ for $\mathrm{NiO}-250$ and $\mathrm{NiO}-800$ samples, respectively. All nanoparticles prepared from decomposition of the precursor above $200^{\circ} \mathrm{C}$ crystallize therefore with the rock salt structure but exhibit different particle sizes.

To get insight on the impact of the particle size on the chemical composition of the nanoparticles we have performed chemical analyses and density measurements $\left(\rho_{\text {exp }}\right)$ on NiO-T samples. The $\rho_{\text {exp }} v s$. T curve is displayed in Figure 2 (see also Table S2). Clearly, samples prepared at temperature higher than $600^{\circ} \mathrm{C}$ (with CS higher than $30 \mathrm{~nm}$ ) exhibit a density quite similar to the theoretical one $\left(\rho_{\text {theo }}=6.81 \mathrm{~g} / \mathrm{cm}^{3}\right)$. At the opposite, density for samples prepared below $600^{\circ} \mathrm{C}$ is lower than $\rho_{\text {theo }}$ and can reach value as low as $5.14 \mathrm{~g} / \mathrm{cm}^{3}$ for $\mathrm{T}$ equal to $250^{\circ} \mathrm{C}$ (CS of $\left.2.3 \mathrm{~nm}\right)$. At this stage, the weight oxygen content $(\mathrm{O} w \mathrm{t} \%)$ of each samples was determined by the inert gas fusion method (Figure S5 and Table S2). Samples prepared at low temperatures clearly evidenced an oxygen concentration much higher (e.g. $26.8 \mathrm{wt} \%$ for NiO-250) than the expected one for $1: 1 \mathrm{Ni}: \mathrm{O}$ stoichiometric materials (i.e. $21.41 \%$ ). However, when synthesis temperature increases, the oxygen weight percentage tends to decrease to reach the theoretical value expected for a 1 by 1 stoichiometry. Thus, the discrepancy in the density measurements at low $\mathrm{T}$ can be assigned to a nickel off-stoichiometry $\left(\mathrm{Ni}_{1-\mathrm{x}} \mathrm{O}\right)$, the refined cell volumes re- 
maining quite similar for all samples (Table S2). For "NiO" nanoparticles with spherical shape and hypothetical $\mathrm{Ni}_{1-\mathrm{x}} \mathrm{O}$ chemical composition, the density can be written $\rho_{(\exp )}=(\mathrm{Z} \times \mathrm{M}) /\left(\mathrm{N}_{\mathrm{A}} \times \mathrm{V}_{\text {cell }}\right)$ where $\mathrm{Z}, \mathrm{M}, \mathrm{N}_{\mathrm{A}}$ and $\mathrm{V}_{\text {cell }}$ are the number of formula unit per unit cell, the molar mass of $\mathrm{Ni}_{1-\mathrm{x}} \mathrm{O}$, the Avogadro number and the volume of the unit cell. Subsequently, the nickel deficiency in $\mathrm{Ni}_{1-\mathrm{x}} \mathrm{O}$ can be calculated from the density measured experimentally and the cell volume determined by Rietveld refinement. Figure 2 displays the calculated $\mathrm{x}$ value of the $\mathrm{Ni}_{1-\mathrm{x}} \mathrm{O}$ samples versus $\mathrm{T}$. Clearly amazing $\mathrm{x}$ values as high as $0.30,0.23$ and 0.18 are calculated for $\mathrm{NiO}-250, \mathrm{NiO}-300$ and $\mathrm{NiO}-350$ samples. When synthesis temperatures increase, $\mathrm{x}$ values progressively decrease to reach more reasonable values at $c a$. $450^{\circ} \mathrm{C}$, and finally tend to zero for T higher than $600^{\circ} \mathrm{C}$.

Consequently, our study clearly confirms that the stoichiometry of the nanoparticle (i.e. the $\mathrm{Ni}: \mathrm{O}$ ratio) is strongly correlated to the particle size. Two models can be envisioned to explain the origin of such high Ni vacancy rates. Either nickel vacancies are homogeneously distributed over the whole material or nickel vacancies are segregated at the surface of nanoparticles. The former hypothesis

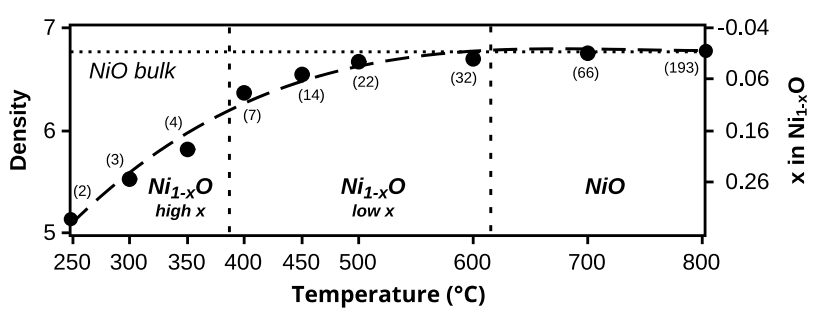

Figure 2. Evolution of the density and the Ni off-stoichiometry of NiO-T samples versus their synthesis temperature. The dashed line has to be regarded as a guide to the eyes. Calculated crystallite sizes (in nanometers) are indicated within brackets.

may be discarded as it would imply an incredible stability of the crystal structure type to accept such high concentrations of defects. Moreover, the segregation of metal vacancies at the surface of the nanoparticles was already observed for $\mathrm{Zn}_{1-\mathrm{x}} \mathrm{O}$ nanoparticles synthesized by thermal decomposition of $\mathrm{ZnO}_{2} \cdot{ }^{34-35}$ The density $v s$. particle size curve was then successfully explained by a core-shell model involving the segregation of metal vacancies at the surface. This model is extended here to $\mathrm{NiO}$ nanoparticles by considering a core consisting of $\mathrm{NiO}$ bulk (i.e. a stoichiometric $\mathrm{NiO}$ ) and a shell of an oxygen rich ( $\mathrm{Ni}$ poor) material. Under oxidizing conditions (decomposition of the $\mathrm{Ni}_{3} \mathrm{O}_{2}(\mathrm{OH})_{4}$ oxygenrich precursor in air), it is reasonable to anticipate that the surface of the synthesized "NiO" samples would be likely composed of a layer of oxygen atoms or hydroxyl groups. To some extent, the shell could be viewed as a passivating layer that might contain altogether species as $\mathrm{O}^{2-}, \mathrm{OH}^{-}, \mathrm{CO}_{3}{ }^{2-}$ or $\mathrm{H}_{2} \mathrm{O}$. In this core-shell model, the ratio of the top-layer thickness (e) over the total particle radius $(\mathrm{R})$ will be large for a nanoparticle but will decrease when the particle grows up as detailed in Figure S6a. Namely, based on a simple mathematical treatment with successive iterations on the e value (Model 1, see SI for methodology), the thickness of the top-layer can be estimated between $1.3 \AA$ and $2.5 \AA$ depending on whether the density evolution is fitted versus the crystallite size (Figure S6b) or the specific surface area (Figure S6c). This thickness value is completely consistent with a toplayer made of a single atomic layer passivating naturally the

surface of the nanoparticles and consisting of oxygen or hydroxyl species with Ni-O interatomic distances of $c a$. 1.8A.

This core-shell model was subsequently refined starting from the rock salt structure type of $\mathrm{NiO}$ built upon $\left[\mathrm{NiO}_{6}\right]$ octahedra sharing edges to form a tridimensional edifice. The crystal growth of $\mathrm{NiO}$ was then considered starting from a regular $\left[\mathrm{NiO}_{6}\right]$ polyhedron as a seed. At the very first stage of the growth, this octahedron will be surrounded by 18 nickel atoms that will complete their coordination sphere via the addition of 38 oxygen atoms to be six-fold coordinated. This growth process will pursue as shown in Figure 3a. The particle will maintain its overall octahedral shape throughout its growth as long as oxygen atoms will cover the external surfaces. Namely, the crystal growth procedure will follow a mathematical series called octahedral number $(O n)$ defined as $\mathrm{On}=\mathrm{n} \times\left(2 \mathrm{n}^{2}+1\right) / 3$; On enumerates the total quantity of $\mathrm{Ni}$ and $\mathrm{O}$ atoms within the octahedral particle for odd and even $\mathrm{n}$ number, respectively. Hence, the second, third, fourth, fifth and sixth coordination spheres of $\mathrm{Ni}$ will contain $6 \mathrm{O}$ atoms $(\mathrm{n}=2$, $O n=6), 18 \mathrm{Ni}$ atoms $(\mathrm{n}=3, O n=19), 38 \mathrm{O}$ atoms $(\mathrm{n}=4, O n=44), 66$ $\mathrm{Ni}$ atoms $(\mathrm{n}=5, \mathrm{On}=85)$, and $102 \mathrm{O}$ atoms $(\mathrm{n}=6, O n=146)$, etc. Consequently, at each stage of the growth process, the total number of atoms of nickel and oxygen can be determined, as well as the exact stoichiometry of the nanoparticles and their theoretical density. Table $\mathbf{S 3}$ sums up for even $\mathrm{n}$ values (i.e. oxygen terminated nanoparticles) salient values, namely the number of $\mathrm{Ni}$ and $\mathrm{O}$ atoms, the deviation to the 1:1 stoichiometry, the octahedron diagonal, the particle diameter assimilated to the isovolumic sphere diameter as depicted in Figure 3b inset, and the calculated density. Data are given for octahedral particles with apical distances lower than $6 \mathrm{~nm}$ ( $\mathrm{n}$ from 2 to 14), and at $c a$. 100nm $(\mathrm{n}=242)$ and 400nm $(\mathrm{n}=960)$.

Step 1
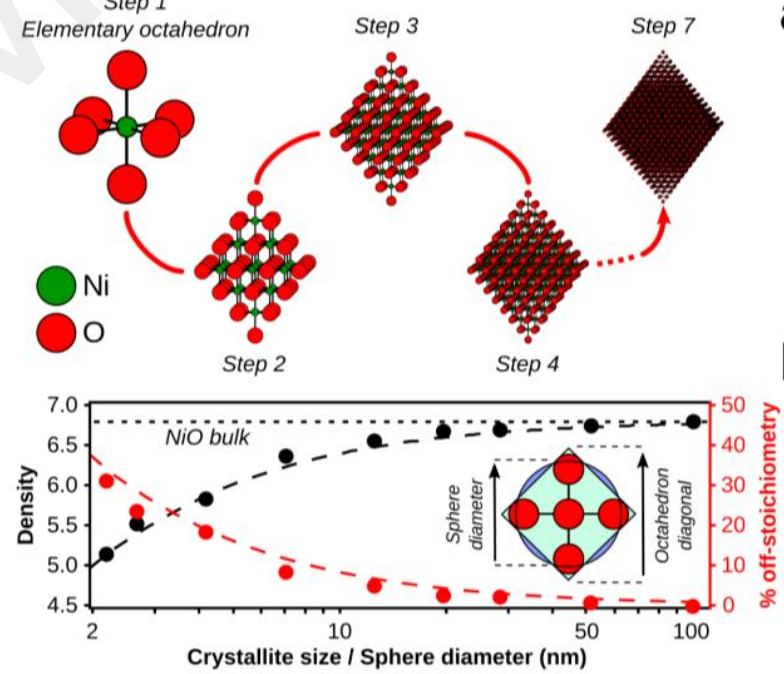

Figure 3. (a) Schematic representation of the crystal growth of $\mathrm{NiO}$ from a $\left[\mathrm{NiO}_{6}\right]$ seed as described in the text. (b) Evolution of the measured density (black dots) and the calculated $\mathrm{Ni}$ offstoichiometry (red dots) in "NiO" vs. crystal size, and comparison with models (dotted lines) where crystal size is assimilated to the isovolumic sphere diameter $\left(\varnothing_{\text {sphere }}\right)$.

As illustrated in Figure 3b, a gradual increase of the density $v$. the isovolumic sphere diameter $\varnothing_{\text {sphere }}$ is observed up to tend towards the measured bulk density of $6.81 \mathrm{~g} / \mathrm{cm}^{3}$ for CS larger than $100 \mathrm{~nm}$. This goes along with a decrease of the $\mathrm{Ni}$ offstoichiometry that shifts from the experimental high value of 
about $30 \%$ for particles size of $2.5 \mathrm{~nm}$ to value almost null for particles larger than $100 \mathrm{~nm}(\leq 1.2 \%)$ and $400 \mathrm{~nm}(0.3 \%)$. A very good correlation between theory and experiment is witnessed. This clearly proves that our core-shell model describes very well for the "NiO" nanoparticle. The core can be regarded as NiO bulk, and the shell as an oxygen single layer that naturally passivates the metallic surface. According to this model, it is possible to adjust the stoichiometry of " $\mathrm{Ni}_{1-\mathrm{x}} \mathrm{O}$ " materials via a fine control of the particle size.

At the nanoscale, the contribution of the surface passivation is such that it drastically modifies the chemical composition of the "NiO" particles, and potentially its physical properties. For this reason, we have measured the magnetic properties of the "NiO" nanoparticles. Many works have indeed reported the appearance of ferromagnetism in $\mathrm{NiO}$ nanoparticle. ${ }^{36-39}$ Figure 4a displays the RT magnetization (M) of NiO-250 and NiO-800 samples vs. magnetic field. Nickel oxide grown at $800{ }^{\circ} \mathrm{C}$ with almost no $\mathrm{Ni}$ vacancies (largest particle size) exhibits no trace of ferromagnetism, which agrees with the commonly reported antiferromagnetic properties of bulk $\mathrm{NiO}$. Conversely, the magnetization of the smallest nickel oxide nanoparticles (NiO-250) with a large Ni offstoichiometry displays a clear RT ferromagnetic contribution. Figure $4 \mathbf{b}$ shows the saturation magnetization at 0.5 Tesla and RT for nanoparticles synthesized in the $250-800^{\circ} \mathrm{C}$ range. A clear trend is observed: the lower the particle size, the higher the ferromagnetic contribution. Our observation clearly suggests that the presence of $\mathrm{Ni}$ vacancies at the vicinity of the surface is at the origin of this ferromagnetic behavior. It is therefore in direct line with previous reports that also points out the prominent role of $\mathrm{Ni}$ vacancies in the vicinity of the surface of nanoparticles in the appearance of this ferromagnetic contribution. ${ }^{36-39}$
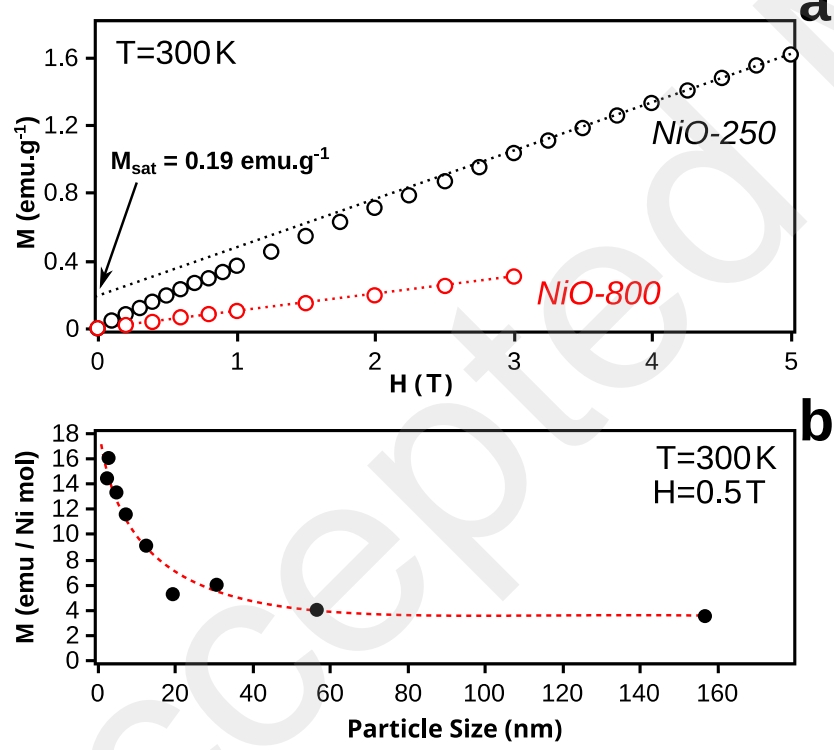

Figure 4. (a) M-H curves measured at $300 \mathrm{~K}$ for $\mathrm{NiO}-250$ and $\mathrm{NiO}-800$. (b) Evolution of magnetization at $300 \mathrm{~K}$ per Ni mol vs. particle size for NiO-T samples.

In summary, the attempts to synthesize nickel oxide via the thermal decomposition of $\mathrm{Ni}_{3} \mathrm{O}_{2}(\mathrm{OH})_{4}$ at low temperature leads to nanoparticles with a chemical composition exceptionally far away from the expected one (i.e. 1:1), with a metal deficiency up to $30 \%$. Our work shows that besides the quantum size effect a chemical size effect has often to be taken into account to understand the behavior of transition metal oxide nanoparticles and explain the change of their physical properties with decreasing the particle size.

\section{ASSOCIATED CONTENT}

\section{Supporting Information}

The Supporting Information is available free of charge on the ACS Publications website $\mathrm{xxxx}$ at DOI: xxxx.

Materials preparation, characterization methods, X-ray diagrams, thermal analysis measurements, TEM photographs, density $v s$. particle size and associated tables (PDF)

\section{AUTHOR INFORMATION}

\section{Corresponding Authors}

* E-mail: francois.chevire@univ-rennes1.fr

* E-mail: stephane.jobic@cnrs-imn.fr

\section{ACKNOWLEDGMENT}

B.P. is indebted to University of Rennes and CNRS for their financial support.

\section{REFERENCES}

(1) De Souza, S.; Visco, S. J.; De Jonghe, L. C. Thin-Film Solid Oxide Fuel Cell with High Performance at Low Temperature. Solid State Ion. 1997, 98, 57-6.

(2) Ricoul, F.; Subrenat, A., Joubert, O.; Le Gal La Salle, A. Electricity Production from Lignocellulosic Biomass by Direct Coupling of a Gasifier and a Nickel/Yttria-Stabilized ZirconiaBased Solid Oxide Fuel Cell. Part 1: From Gas Production to Direct Electricity Production. Int. J. Hydrog. Energy 2017, 42, 21215-21225.

(3) Malzbender, J.; Wessel, E.; Steinbrech, R. W. Reduction and Re-Oxidation of Anodes for Solid Oxide Fuel Cells. Solid State Ion. 2005, 176, 2201-2203.

(4) Bruce, P. G.; Scrosati, B.; Tarascon J-M. Nanomaterials for Rechargeable Lithium Batteries. Angew. Chem. Int. Ed. 2008, 47, 2930-2946.

(5) Needham, S.A.; Wang, G.X.; Liu, H.K. Synthesis of NiO Nanotubes for Use as Negative Electrodes in Lithium Ion Batteries. J. Power Sources 2006, 159, 254-257.

(6) Hao Liu, H.; Wang, G.; Liu, J.; Qiao, S.; Ahn, H. Highly Ordered Mesoporous NiO Anode Material for Lithium Ion Batteries with an Excellent Electrochemical Performance. J. Mater. Chem. 2011, 21, 3046-3052.

(7) Zhang, J.; Tu, J. P.; Xia, X.H.; Qiao, Y.; Lu, Y. An All-SolidState Electrochromic Device Based on $\mathrm{NiO} / \mathrm{WO}_{3}$ Complementary Structure and Solid Hybrid Polyelectrolyte. Sol. Energy Mater. Sol. Cells 2009, 93, 1840-1845.

(8) Moulki, H.; Park, D. H.; Min, B-K.; Kwon, H.; Hwang, S-J.; Choy, J-H.; Toupance, T.; Campet, G.; Rougier, A. Improved Electrochromic Performances of NiO based Thin Films by Lithium Addition: From Single Layers to Devices. Electrochim. Acta 2012, 74, 46-52.

(9) Granqvist; C. G. Electrochromic Devices. J. Eur. Ceram. Soc. 2005, 25, 2907-2912.

(10) Dirksen, J. A.; Duval, K.; Ring, T. A. NiO Thin-Film Formaldehyde Gas Sensor. Sens. Actuator B-Chem 2001, 80, 106115.

(11) Hotovy, I.; Rehacek, V.; Siciliano, P.; Capone, S.; Spiess, L. Sensing Characteristics of $\mathrm{NiO}$ Thin Films as $\mathrm{NO}_{2}$ Gas Sensor. Thin Solid Films 2002, 418, 9-15. 
(12) Steinebach, H.; Kannan, S.; Rieth, L.; Solzbacher, F. $\mathrm{H}_{2}$ gas sensor performance of $\mathrm{NiO}$ at high temperatures in gas mixtures. Sens. Actuators B-Chem 2010, 151, 162-168.

(13) Gondal, M. A.; Sayeed, M. N.; Alarfaj, A. Activity Comparison of $\mathrm{Fe}_{2} \mathrm{O}_{3}, \mathrm{NiO}, \mathrm{WO}_{3}, \mathrm{TiO}_{2}$ Semiconductor Catalysts in Phenol Degradation by Laser Enhanced Photo-Catalytic Process. Chem. Phys Lett. 2007, 445, 325-330.

(14) Li, L.; Duan, L., Wen, F., Li, C; Wang, M.; Hagfeldt, A.; Sun, L. Visible light Driven Hydrogen Production from a PhotoActive Cathode Based on a Molecular Catalyst and Organic DyeSensitized p-type Nanostructured NiO. Chem. Commun. 2012, 48, 988-990.

(15) Wang, D.; Xu, R.; Wang, X.; Li, Y. NiO Nanorings and their Unexpected Catalytic Property for CO Oxidation. Nanotechnology 2006, 17, 979-983.

(16) He, J.; Lindström, H.; Hagfeldt, A.; Lindquist, S-E. DyeSensitized Nanostructured p-type Nickel Oxide Film as a Photocathode for a Solar Cell. J. Phys. Chem. B 1999, 103, 8940-8943.

(17) Odobel, F.; Le Pleux, L.; Pellegrin, Y.; Blart, E. New Photovoltaic Devices Based on the Sensitization of p-type Semiconductors: Challenges and Opportunities. Accounts Chem. Res. 2010, 43, 1063-1071.

(18) Perera, I. R.; Daeneke, T.; Makuta, S.; Yu, Z.; Tachibana, Y.; Mishra, A.; Bäuerle, P.; Ohlin, C. A.; Udo Bach, U.; Spiccia L. Application of the Tris(acetylacetonato)Iron(III)/(II) Redox Couple in p-Type Dye-Sensitized Solar Cells. Angew. Chem. Int. Ed. 2015, 54, 3758-3762.

(19) Russo , U.; Ielmini , D.; Cagli, C.; Lacaita, A. L. Filament Conduction and Reset Mechanism in NiO-Based ResistiveSwitching Memory (RRAM) Devices. IEEE Trans. Electron Devices 2009, 56, 186-192.

(20) Kim, D. C.; Seo, S.; Ahn, S. E.; Suh, D.-S.; Lee, M. J.; Park, B.-H.; Yoo, I. K. ;Baek, I. G.; Kim, H.-J.;Yim, E. K.;Lee, J. E.;Park, S. O.;Kim, H. S.;Chung, U-In; Moon, J. T.; Ryu, B. I. Electrical Observations of Filamentary Conductions for the Resistive Memory Switching in NiO films. Appl. Phys. Lett. 2006, 88, 202102.

(21) Lee, M-J.; Han, S.; Jeon, S. H.; Park, B. H.; Kang, B. S.; Ahn, S-E.; Kim, K. H.; Lee, C. B.; Kim, C. J.; Yoo, I-K.; Seo, D. H.; Li, X-S.; Park, J-B.; Lee, J-H., Park, Y. Electrical Manipulation of Nanofilaments in Transition-Metal Oxides for ResistanceBased Memory. Nano Lett. 2009, 9, 1476-1481.

(22) Kodama, R. H.; Makhlouf, S. A.; Berkowitz, A. E. Finite Size Effects in Antiferromagnetic NiO Nanoparticles. Phys. Rev B. 1997, 79, 1393-1396.

(23) Ichiyanagi,Y.; Wakabayashi, N.; Yamazaki, J.; Yamada, S.; Kimishima, Y.; Komatsu, E.; Tajima, H. Magnetic Properties of NiO Nanoparticles. Physica B 2003, 329-333, 862-863.

(24) Cooper, J. F. K.; Ionescu, A.; Langford, R. M., Ziebeck, K. R. A.; Barnes, C. H. W., Gruar, R.; Tighe, C.; Darr, J. A.; Thanh, N. T. K., Ouladdiaf, B. Core/Shell Magnetism in NiO Nanoparticles, J. Appl. Phys. 2013, 114, 083906.

(25) Mott, N. F. The Basis of the Electron Theory of Metals, with Special Reference to the Transition Metals. Proc. Phys. Soc. A 1949, 62, 416-422.

(26) Tjernberg, O.; Söderholm, S.; Karlsson, U. O.; Chiaia, G.; Qvarford, M.; Nylén, H.; Lindau, I. Resonant Photoelectron Spectroscopy on NiO. Phys. Rev. B 1996, 53, 10372.

(27) Schuler, T. M.; Ederer, D. L.; Itza-Ortiz, S.; Woods, G. T.; Callcott, T. A.; Woicik, J. C. Character of the Insulating State in NiO: A Mixture of Charge-Transfer and Mott-Hubbard Character. Phys Rev B 2005, 71, 115113.
(28) Gonzalez-Elipe,A. R.; Holgado, J. P.; Alvarez, R.; Munuera, G. Use of Factor Analysis and XPS To Study Defective Nickel Oxide. J. Phys. Chem. 1992, 96, 3080-3086.

(29) Boschloo, G.; Hagfeldt, A. Spectroelectrochemistry of Nanostructured NiO. J. Phys. Chem. B 2001, 105, 3039-3044

(30) Korošec, R. C.; Bukovec, P. Sol-Gel Prepared NiO Thin Films for Electrochromic Applications. Acta Chim. Slov. 2006, 53, 136-147

(31) Biju, V.; Abdul Khadar, M. DC Conductivity of Consolidated Nanoparticles of NiO. Mater. Res. Bull. 2001, 36, 21

(32) Madhu, G.; Biju, V. Effect of $\mathrm{Ni}^{2+}$ and $\mathrm{O}^{2-}$ Vacancies on the Electrical and Optical Properties of Nanostructured Nickel Oxide Synthesized Through a facile Chemical Route. Physica E. 2014, 60, 200.

(33) Polteau, B.; Tessier, F.; Cheviré, F.; Cario, L.; Odobel, F.; Jobic, S. Synthesis of Ni-poor NiO Nanoparticles for p-DSSC Applications. Solid State Sci. 2016, 54, 37-42.

(34) Renaud, A.; Cario, L.; Rocquelfelte, X.; Deniard, P.; Gautron, E.; Faulques, E.; Das, T.; Cheviré, F.; Tessier, F., Jobic, S. Unravelling the Origin of the Giant $\mathrm{Zn}$ Deficiency in Wurtzite Type ZnO Nanoparticles. Sci. Rep. 2015, 5, 12914.

(35) Chavillon, B.; Cario, L.; Renaud, A.; Tessier, F.; Cheviré, F.; Boujtita, M.; Pellegrin, Y.; Blart, E.; Smeigh, A.; Hammarström, L.; Odobel, F.; Jobic, S. p-type Nitrogen Doped ZnO Nanoparticles Stable Over Two Years in Ambient Conditions. J. Am. Chem. Soc. 2012, 134, 464-470.

(36) Mandal, S.; Banerjee, S.; Menon, K. S. R. Core-shell model of the vacancy concentration and magnetic behavior for antiferromagnetic nanoparticle. Phys. Rev. B 2009, 80, 214420.

(37) Mandal, S.; Menon, K. S. R.; Mahatha, S. K.; Banerjee, S. Finite size versus surface effects on magnetic properties of antiferromagnetic particles. Appl. Phys. Lett. 2011, 99, 232507.

(38) Cooper, J. F. K., Ionescu, A.; Langford, R. M.; Ziebeck, K. R. A., Barnes, C. H. W.,Gruar, R., Tighe, C.; Darr, J. A.; Thanh, N. T. K.; Ouladdiaf, B. Core/shell magnetism in NiO nanoparticles. J. Appl. Phys. 2013, 114, 083906.

(39) Chen, Z-Y.; Chen, Y.; Zhang, Q. K.; Tang, X. Q.; Wang, D. D.; Chen, Z. Q.; Mascher, P.; Wang, S. J. Vacancy-Induced Ferromagnetic Behavior in Antiferromagnetic NiO Nanoparticles: A Positron Annihilation Study. ECS J. Solid State Sci. Technol. 2017, 6, P798-P804. 